\title{
Evaluation of the Plant Necromass Component: Methodological Approaches and Estimates in Atlantic Forest, Northeast Brazil
}

\author{
Nathan Castro Fonsêca ${ }^{1}$ (D), Isabelle Maria Jacqueline Meunier ${ }^{1}$ (D), \\ Ana Carolina Borges Lins e Silva ${ }^{1}$ \\ ${ }^{1}$ Universidade Federal Rural de Pernambuco - UFRPE, Recife, PE, Brasil.
}

\begin{abstract}
Necromass is a crucial component for the forest structure. However, there are few studies of necromass quantification in tropical rainforests and lack of efficient sampling methods. This research aimed at verifying the accuracy and effectiveness of sampling methods (Line-intersect sampling - LIS versus fixed area plots - FA) for the estimation of necromass in a tropical rainforest. The accuracy and efficiency of the methods were evaluated through descriptive statistics, paired t-test, ANOVA and relative efficiency. LIS method was more accurate and efficient, but it requires high sampling to meet sample error of $15 \%$. Necromass at the forest fragment studied accounted for about $12.28 \%$ of the tree biomass. These findings show the importance of this compartment inclusion when quantifying carbon stocks in humid tropical forests, which acts as a true reservoir of carbon.
\end{abstract}

Keywords: sampling, fixed area, fallen dead wood, transect. 


\section{INTRODUCTION}

Forests naturally produce woody residues through the fall of dead branches and trunks or whole trees (Cruz \& Silva, 2009). This vegetal detritus, known as necromass, constitute a crucial component of the forest structure acting both in quantitative aspect and in the functioning of the ecosystem (Sanchez et al., 2009; Gove et al., 2012; Bassett et al., 2015). Necromass stores a considerable amount of carbon (Russell et al., 2015; Iwashita et al., 2013). It is a sink of other nutrients on the forest floor beside being a habitat for a wide variety of organisms (Sefidi \& Marvie Mohadjer, 2010). Necromass is divided into two categories: fine litter or litter (diameter of pieces $<2 \mathrm{~cm}$ ) and coarse litter (diameter $>2 \mathrm{~cm}$ ) (Palace et al., 2012). The coarse litter is divided into standing dead wood and fallen or downed necromass (Barbosa et al., 2009; Palace et al., 2012).

The coarse litter stock is responsible for a high percentage of above-ground carbon stock in tropical forests, ranging from $10 \%$ to $20 \%$ (Houghton et al., 2001 ) or $20 \%$ to $40 \%$ (Palace et al., 2012). The high percentage of coarse litter stock and its strong relation to carbon storage, nutrient cycling, global warming and global climate change reinforces the need to include the necromass compartment in forest inventories (Weedon et al., 2009; Zhou et al., 2014). Using these compartments, it is possible to access the amount of $\mathrm{C}$ released to the soil and atmosphere adequately (Palace et al., 2012; Zaninovich et al., 2016), becoming an essential attribute for an efficient forest management.

Although necromass contributes considerably to the organic matter and total above-ground carbon, the quantification and dynamics in tropical forests were mostly conducted in areas of extensive natural forest cover, particularly in the Amazon (Rice et al., 2004; Chao et al., 2009; Silva et al., 2016). In reduced and fragmented forests in anthropogenic landscapes, such as the small and numerous remnants of the Atlantic Forest the studies are restrict. Ribeiro et al. (2012) determined the volumes of dead matter in a remnant of Mixed Ombrophylous Forest in Paraná. Cardoso et al. (2012) quantified coarse woody debris in forest remnants in Santa Catarina. The absence of data hinders understanding the potential of forest fragments in provide ecosystem services, especially regarding carbon stocks.
Above-ground necromass quantification in fragmented landscapes faces the high heterogeneity of landscapes in the Atlantic Forest, concerning age, size, shape and patch isolation, type of matrix and existing disturbances. This scenario interferes on the determination of sample units in terms of size and number, and the methodological approach either by area or by transect (Deus et al., 2018). Searching for the most appropriate sampling method for quantifying the necromass and obtaining information related to ecosystem services and forest dynamics becomes increasingly important (Stinson et al., 2011). There is a lack of studies in the Atlantic Forest biome. To fill this gap and allow better planning and valorization of the services by forest remnants, this research aimed at comparing the accuracy and efficiency of two methods for estimating the above-ground plant necromass in a fragment of tropical rainforest.

\section{MATERIAL AND METHODS}

\subsection{Study area}

The study was carried out in a remnant of mature Atlantic Forest located in the State Park Dois Irmãos (SPDI), a protected area of the State of Pernambuco, Northeast Brazil ( $7^{\circ} 57^{\prime} 40^{\prime \prime}$ S - 8 $00^{\circ} 52^{\prime \prime}$ S; 56'23" $\left.\mathrm{W}-34^{\circ} 57^{\prime} 31^{\prime \prime} \mathrm{W}\right)$. The forest covers 384 ha on a peri-urban matrix under negative anthropogenic impacts. The vegetation consists of Lowland Dense Ombrophylous Forest type (Lima et al., 2018). The climate is warm and humid, type As' according to Köppen classification. The area has an average annual precipitation of $2417 \mathrm{~mm}$, more intense in autumn-winter. Average monthly temperatures are higher than $23^{\circ} \mathrm{C}$ (data from National Institute of Meteorology: www.inmet.gov.br). The predominant soil types are Latosol, Argisssol and Quartzarenic Neosol, following the Brazilian Soil Database (Benedetti et al., 2011).

\subsection{Data sampling}

Two different methods were used to sample the arboreal necromass: the line-intersect method (LIS), developed by Warren \& Olsen (1964) and adapted by Van Wagner (1968), and the fixed area plot (FA) method.

Data were sampled in four permanent plots following the RAPELD method (Magnusson et al., 
2005), consisting of plots system (250 m x $40 \mathrm{~m}$ each) established systematically and installed by the Program of Biodiversity Research (PPBio), PEDI site. In each plot, five $50 \mathrm{~m}$ transects (LIS Method) were placed in the upper part, along which five $10 \mathrm{~m}$ x $10 \mathrm{~m}$ plots were set up and within these, $5 \mathrm{~m} \times 5 \mathrm{~m}$ subplots in the lower part (AF Method) (Figure 1).

To adjust the volume of the solid obtained for each of the wood pieces for the two evaluated methods, five diameter classes were adopted, divided into small pieces of $2 \mathrm{~cm} \times 3.9 \mathrm{~cm} ; 4 \mathrm{~cm} \times 5.9 \mathrm{~cm} ; 6 \mathrm{~cm} \times 7.9 \mathrm{~cm}$; $8 \mathrm{~cm} \times 9.9 \mathrm{~cm}$ and large with a diameter $(\varnothing)$ greater than $10 \mathrm{~cm}$.

A tactile-visual categorization of the degree of decomposition of each wood pieces was performed following the criteria of Chao \& Phillips (2005), modified by Barbosa et al. (2009). Wood pieces were classified into three groups: DD1, newly fallen or high resistance parts, without signs of attack from insects or fungi; DD2, parts with slight signs of insects and fungi harm, usually parts with small hollows but high resistant to manual touch; DD3, parts in an advanced stage of decomposition with signs of rot in different stages that, in most cases, shattered at the manual touch.

For each degree of decomposition (DD1, DD2 and DD3), 30 samples were collected to calculate the basic density. The samples were collected removing discs $(5 \mathrm{~cm})$ from wood pieces with different diameters and degrees of decomposition and equally distributed along all transects and installed plots. Basic densities were determined by the water immersion method, following the NBR 11941 standard of the Brazilian Association of Technical Standards, ABNT (2003).

\subsection{Estimates of volumetric stock of dead wood}

\subsubsection{LIS method}

LIS method measures the diameter of each wood piece that intercepts the transect. There were installed 20 transects of $50 \mathrm{~m}$ length to sample large pieces $(\varnothing>10 \mathrm{~cm})$ and small pieces $(\varnothing \geq 2 \mathrm{~cm}$ and $\leq 10 \mathrm{~cm})$. All transects were allocated according to the level curve of the terrain using a clinometer and marked by an alignment made of nylon string and fixed with

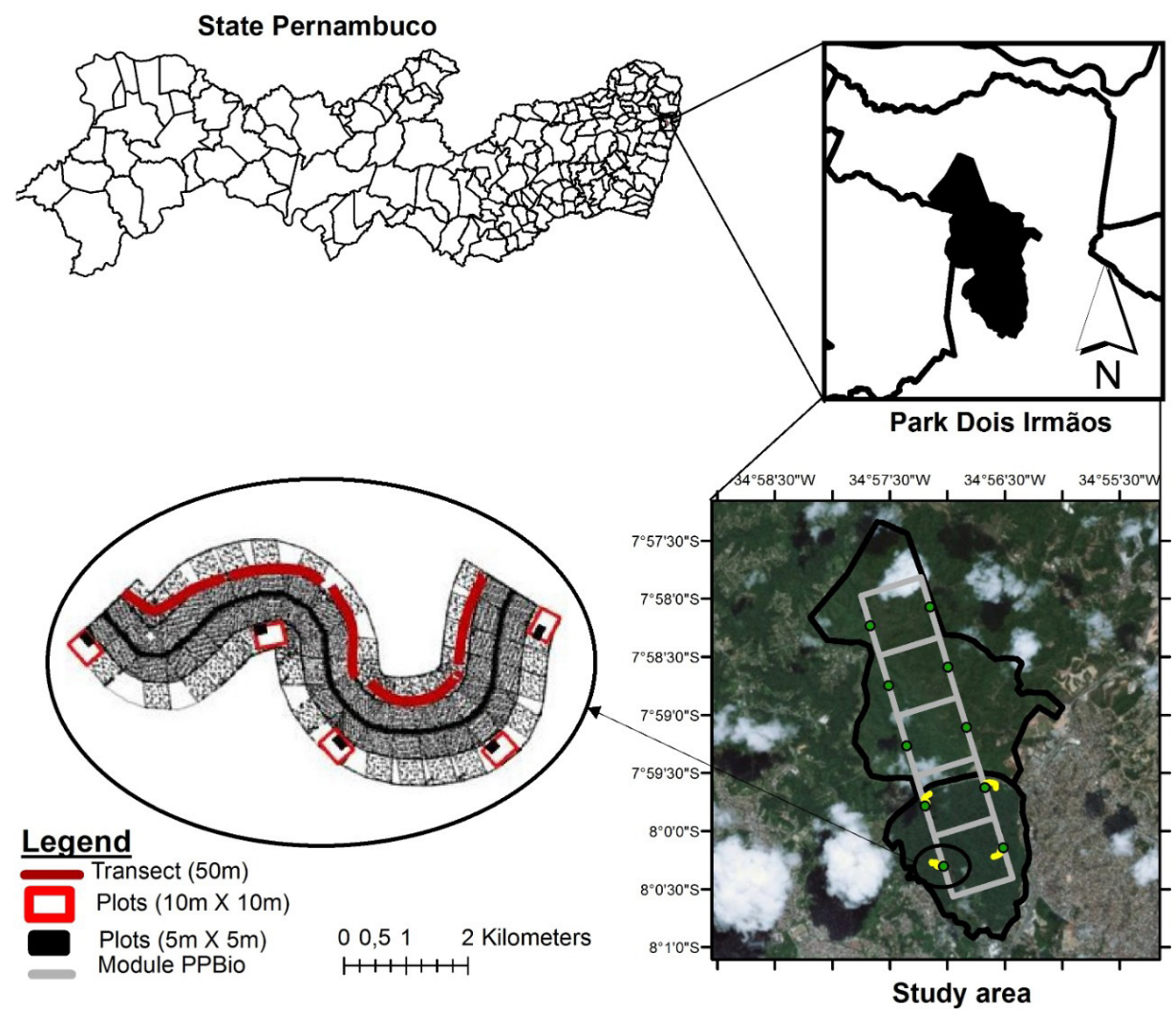

Figure 1. Location of transects and plots set up in the study area, Dois Irmãos State Park, Recife-PE, Brazil. 
stacks every $10 \mathrm{~m}$. The wood pieces that intercepted the transect were categorized according to the degree of decomposition and the diameters measured with a tape measure to calculate the estimated volume $\left(\mathrm{V}_{E s t}\right)$, using Van Wagner (1968) equation 1.

$\boldsymbol{V}_{\boldsymbol{E} \boldsymbol{t}}=\frac{{\partial^{2}}^{2} \times d^{2}}{8 \times L}$

Where: $V_{\text {Est }}=$ estimated volume $\left(\mathrm{m}^{3} \cdot \mathrm{ha}^{-1}\right) ; \mathrm{d}=$ diameter of each piece in the sample line; $\mathrm{L}=$ length of a sample line $(50 \mathrm{~m})$.

\subsubsection{FA method}

For FA method, 20 plots $(10 \mathrm{~m} \mathrm{x} 10 \mathrm{~m})$ were used to sample large pieces $(\varnothing>10 \mathrm{~cm})$. In each plot, subplots ( $5 \mathrm{~m} \times 5 \mathrm{~m}$ ) were used to sample the small pieces $(\varnothing \geq 2 \mathrm{~cm}$ and $\leq 10 \mathrm{~cm})$, as shown in item 2.2, Figure 1. Volume of large and small pieces was obtained by Smalian's rigorous cubing method, which consists of measuring the diameters at the end of each section of the trunk of all fallen dead trees or branches with using a metal and plastic tape measures. Estimated volume of each section was determined by the equation 2 of Smalian:

$V_{E s t}=L\left[\frac{\pi\left(D_{I} / 2\right)^{2}+\pi\left(D_{2} / 2\right)^{2}}{2}\right]$

Where: $V_{\text {Est }}=$ estimated volume $\left(\mathrm{m}^{3}\right) ; \mathrm{L}(\mathrm{m})=$ length of measured piece; $\mathrm{D}_{1,2}=\operatorname{diameter}(\mathrm{m})$, at both ends.

\subsection{Calculation of necromass for the different sampling methods}

Necromass stock was calculated using the estimated volume $\left(\mathrm{V}_{E s t}\right)$ in the field and the basic density $\left(\mathrm{D}_{b}\right.$ in $\left.\mathrm{g} . \mathrm{cm}^{3}\right)$ by diameter category and decomposition degree. The necromass was obtained by multiplying the volume of each category by their respective basic densities $\left(\mathrm{g} / \mathrm{cm}^{3}\right)$ (Equation 3):

Necr $=V_{E s t} * D_{b}$

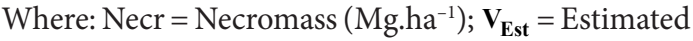
volume $\left(\mathrm{m}^{3} \cdot \mathrm{ha}^{-1}\right) ; \mathbf{D}_{\mathbf{b}}=$ Basic density $\left(\mathrm{g} \cdot \mathrm{cm}^{3}\right)$.

\subsection{Data analysis}

To verify the existence of differences between the volume $\left(\mathrm{m}^{3} \mathrm{ha}^{-1}\right)$ and the necromass $\left(\mathrm{Mg} \cdot \mathrm{ha}^{-1}\right)$ obtained by the different methods by degree of decomposition, we used a paired $t$-test and ANOVA at $5 \%$ of probability in Software R.3.3.1 (R Development Core Team 2016). Sampling accuracy was evaluated, considering a 5\% probability level and sample intensity with 15\% error limit. Descriptive statistics analyzed the results obtained by each method: Mean, variance, standard deviation, mean variance, standard error of the mean, and the coefficient of variation, absolute error, and relative error.

The efficiency of sampling methods was evaluated by measuring the total time from the plots and transects installation to the measurement of the last piece of fallen wood. With the time measured, the relative efficiency calculation was performed (Miranda et al., 2015), considering the coefficient of variation of the sampling methods, by equation 4 :

$\mathbf{R E}=\frac{1}{T_{i}^{*} C V^{2}}$

Where: $\mathrm{RE}=$ relative efficiency; $\mathrm{Ti}=$ Time of allocation and measurement of variables in sample units (h); $\mathrm{CV}=$ Coefficient of variation .

\section{RESULTS AND DISCUSSION}

\subsection{Basic density of fallen dead wood}

The basic density of dead woods is a variable of difficult measurement in pieces in an advanced degree of decomposition. There are no densities estimated at different degrees of decomposition for Atlantic Forest. Thus, the present research presents densities in three degrees of decomposition (DD1, DD2 and DD3) (Table 1).

Early-stage (DD1) pieces exhibit higher density, followed by the intermediate and final degree of decomposition, similar to Silva et al. (2016) findings in the Amazon forest. This is an expected result since the more decomposed material tends to have a smaller mass and a larger volume due to fibers loosening by

Table 1. Mean density ( \pm standard deviation) of dead wood for different decomposition degrees, Dois Irmãos State Park, Recife, Pernambuco, Brazil.

\begin{tabular}{|cc|} 
Decomposition degree & Basic density $\left(\mathbf{g} \cdot \mathbf{c m}^{-3}\right)$ \\
\hline DD1 & $0.6858(0.02)$ \\
DD2 & $0.5659(0.02)$ \\
DD3 & $0.4252(0.03)$ \\
\hline
\end{tabular}


decomposition. Thus, forests with a high decomposition rate have a higher volumetric stock and consequently lower plant necromass.

\subsection{Estimates of volume and plant necromass}

\subsubsection{Small pieces}

We measured 924 pieces of dead wood using both sampling methods (LIS versus FA). LIS method measured $62 \%$ of all evaluated pieces, obtaining an average volume of $12.56 \mathrm{~m}^{3}$. ha- . We recorded 346 (38\%) pieces and an average volume of $12.03 \mathrm{~m}^{3} \cdot \mathrm{ha}^{-1}$ through FA method. There was no difference $(p$-value $=0.912)$

The volume $\left(\mathrm{m}^{3} \cdot \mathrm{ha}^{-1}\right)$ by diameter classes did not differ $(p$-value $=0.811)$ between the two methods and followed the same pattern, that is, the lowest class accounted for the largest part of the volumetric stock (Figure 2). The high amount of small branches found in the forest explains these results.

The highest percentage of the volume of dead wood in the forest is in the decomposition degree 3 (DD3),

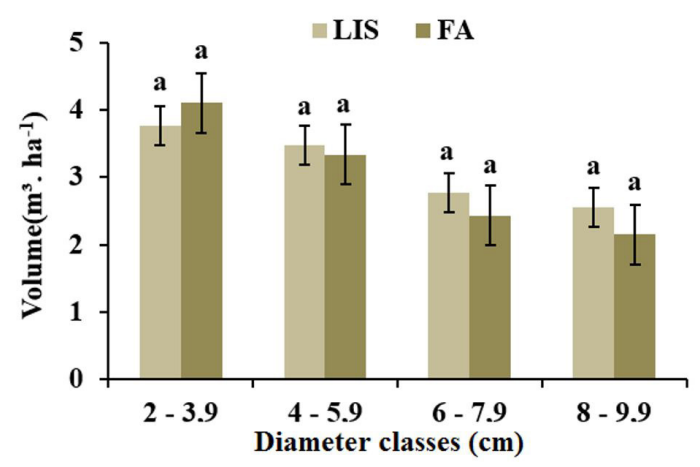

Figure 2. Volume $\left(\mathrm{m}^{3}\right.$. ha $\left.\mathrm{h}^{-1}\right)$ by classes of diameter for the different methods of necromass estimation.

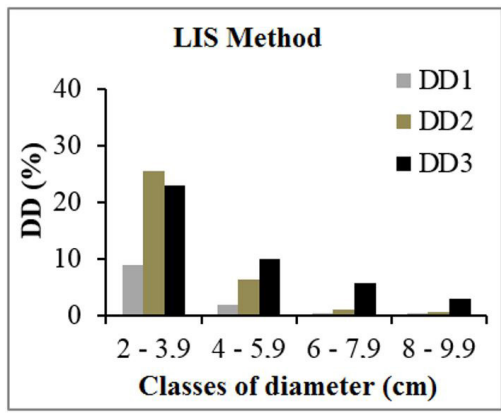
of volumetric estimates.

for both methods, indicating that the area had not suffered recent natural or anthropic events involving small branches falling.

The final decomposition class at the LIS method presented a volume of $7.05 \mathrm{~m}^{3} \mathrm{ha}^{-1}$, representing $56.2 \%$ of the total volume. The intermediate (DD2) and initial (DD1) classes showed $4.84 \mathrm{~m}^{3} \mathrm{ha}^{-1}(38.5 \%)$ and $0.67 \mathrm{~m}^{3} \mathrm{ha}^{-1}(5.3 \%)$, respectively.

We found similar results using the FA method, with DD3 representing $70 \%\left(8.60 \mathrm{~m}^{3} \mathrm{ha}^{-1}\right)$, followed by DD2 and DD1, for a total of $3.0(24 \%)$ and $0.73 \mathrm{~m}^{3} \mathrm{ha}^{-1}$ (6.0\%). Analyzing the DD by classes of diameter for both methods, we verified that the lowest class $(2-3.9 \mathrm{~cm})$ represented $57 \%$ and $66 \%$ of all pieces of dead wood sampled in the forest, respectively, for LIS and FA methods (Figure 3).

The decomposition degree DD3 was higher in all classes, except for small class $(2-3.9 \mathrm{~cm})$ using LIS method, in which $\mathrm{DD} 2$ predominated. These results demonstrate that the studied forest is constantly releasing nutrients to the soil and $\mathrm{CO}_{2}$ to the atmosphere, considering that more than $50 \%$ of the pieces of wood are in DD3.

The tree necromass estimation for the small pieces was similar in both methods (Figure 4).

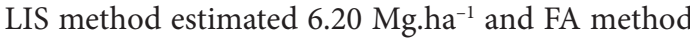
estimated 5.90 Mg.ha-1, without significant differences (p-value $=0.925)$.

Studies show that the necromass stock obtained for small diameters classes $(2<\varnothing<10 \mathrm{~cm})$ ranges from 4 to $9 \mathrm{Mg}^{-h^{-1}}{ }^{-1}$, accounting for $12 \%$ to $21 \%$ of the total dead wood in a forest (Nascimento \& Laurance, 2002). In the Amazon, it is estimated that the dead wood compartment with a diameter $<10 \mathrm{~cm}$ is responsible for $12 \%$ of the total necromass (Rice et al., 2004). These results show the importance of including small

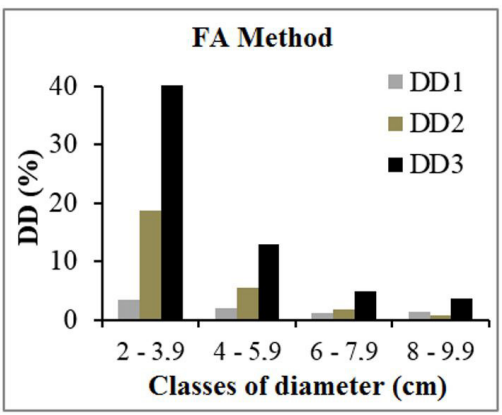

Figure 3. Decomposition degree (DD) by diameter classes for different methods of necromass estimation. 
diameter classes in forest inventories, considering that the non-inclusion of this compartment may lead to underestimation of up to $20 \%$ of the total carbon stock in a tropical forest.

\subsubsection{Coarse pieces}

We found 167 pieces of wood with a diameter greater than $10 \mathrm{~cm}$. LIS method measured $56.28 \%$ of the total of individuals, obtaining an average volume of $51.58 \mathrm{~m}^{3} \mathrm{ha}^{-1}$, whereas FA method recorded 73 individuals $(43.72 \%)$ and an average volume of $47.80 \mathrm{~m}^{3} \mathrm{ha}^{-1}$. The volumetric stock $\left(\mathrm{m}^{3} \cdot \mathrm{ha}^{-1}\right)$ did not differ between the evaluated methods $(\mathrm{p}$-value $=0.813$ ).

We found lower volumes than those found by Rice et al. (2004) for the Amazon forest. The authors found $151.7 \mathrm{~m}^{3} \mathrm{ha}^{-1}$ and $164.2 \mathrm{~m}^{3} \mathrm{ha}^{-1}$, respectively, for FA and LIS methods. The differences in biomass on distinct forest typologies can explain the low stock. According

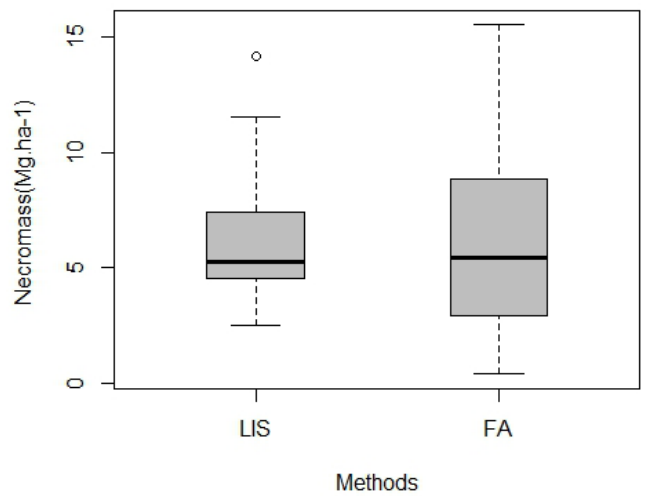

Figure 4. Exploratory analysis of necromass stock $\left(\mathrm{Mg} \mathrm{ha} \mathrm{h}^{-1}\right)$ of small pieces for different methods of necromass estimation. to Chao et al. (2009), forests with a higher amount of aerial biomass show linearly larger accumulations of dead wood. Comparing the total volumetric stock in percentage among all diametric classes, we verified that the class $\varnothing \geq 10 \mathrm{~cm}$ accounted for $81.3 \%$ of the total volumetric stock in the LIS method and $80.2 \%$ in the FA method (Figure 5).

Woody residues with diameters greater than $10 \mathrm{~cm}$ are the main components of the coarse litter in tropical forests, because $80 \%$ of the above-ground biomass consists of trees with diameter above $10 \mathrm{~cm}$ and the total biomass is represented mostly by few and large trees (Nascimento \& Laurance, 2002). In the Atlantic forest, trees with diameters larger than $30 \mathrm{~cm}$ account for $6 \%$ of all individuals and contribute to $72 \%$ of the total biomass, leading to a higher necromass of that diameter class in these forests (Lindner, 2010).

The percentage of the volume of coarse pieces per class of decomposition did not differ from the results found for the small parts, indicating that most of the volume has a high degree of decomposition (DD3), more than $70 \%$ of the total. Using LIS method, the final decomposition class had a volume of $41.2 \mathrm{~m}^{3} \mathrm{ha}^{-1}$, $79.8 \%$ of the total volume. The intermediate (DD2) and initial (DD1) classes had $4.8 \mathrm{~m}^{3} \mathrm{ha}^{-1}$ (9.6\%) and $5.5 \mathrm{~m}^{3} \mathrm{ha}^{-1}(10.6 \%)$, respectively.

Similar results were found using the FA method. DD3 represented 74\% $\left(35.3 \mathrm{~m}^{3} \mathrm{ha}^{-1}\right)$, followed by DD2 and DD1, corresponding to $7.2(15 \%)$ and $5.3 \mathrm{~m}^{3} \mathrm{ha}^{-1}$ (11\%), respectively. These results corroborate with Silva et al. (2016), showing that most of volume consists of the final class of decomposition and the smallest part of volume corresponds to woody material at
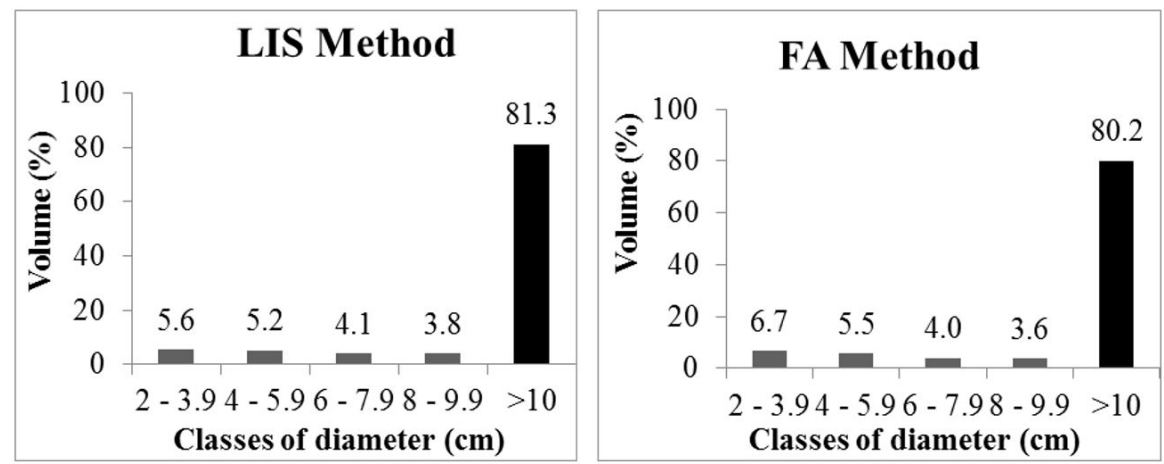

Figure 5. Volumetric stock (\%) by diameter classes, at Dois Irmãos State Park, Recife, PE, Brazil, for different methods of necromass estimation. 
the initial stage of deterioration. The above-ground arboreal necromass for coarse pieces was $25.22{\mathrm{Mg} . h a^{-1}}^{-1}$ using the LIS method, and $24.65{\mathrm{Mg} \cdot \mathrm{ha}^{-1}}^{-1}$ using the FA method (Figure 6), with no significant differences $(\mathrm{p}$-value $=0.946)$.

The estimated necromass was relatively below than that recorded in Amazonian forest. Rice et al. (2004) found a stock of $48 \mathrm{Mg} \cdot \mathrm{ha}^{-1}$ and Chao et al. (2009) found $58.5 \mathrm{Mg} \mathrm{ha}^{-1}$. The smaller number of individuals per hectare $\left(842 \mathrm{ha}^{-1}\right)$ consisting of $88.6 \%$ of the class of diameter 5 to $20 \mathrm{~cm}$ can explain the low stock of necromass in the studied fragments in comparison to Amazonian forest. However, the total arboreal necromass (small and coarse parts) corresponds to $12.28 \%$ (LIS) and $11.94 \%$ (FA) of total biomass above the soil (255.67 Mg.ha ${ }^{-1}$, unpublished data). Other studies found a tree necromass from 6 to $25 \%$ of the

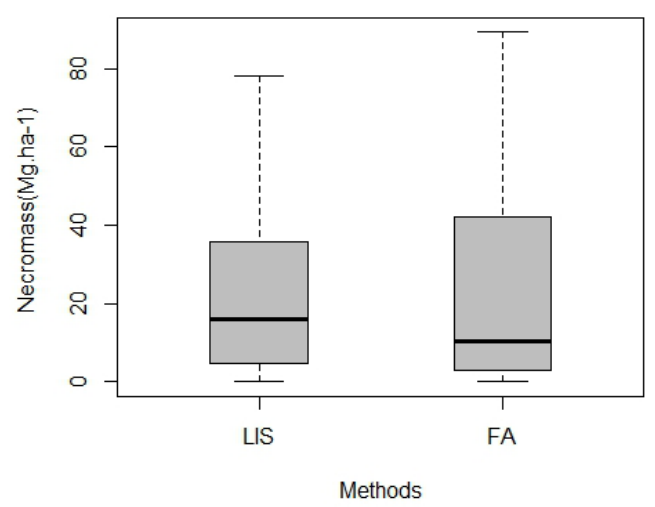

Figure 6. Exploratory analysis of necromassa stock $\left(\mathrm{Mg} \mathrm{ha} \mathrm{h}^{-1}\right)$ of coarse piece for different methods of necromass estimation. total biomass above the soil (Nascimento \& Laurance, 2002; Rice et al., 2004).

\subsection{Comparison between sampling methods (LIS versus FA)}

We did not find differences in volume estimates $\left(\mathrm{m} 3 \mathrm{ha}^{-1}\right)$ and arboreal necromass $\left(\mathrm{Mg} \mathrm{ha}^{-1}\right)$ between the studied sampling methods. However, we observed differences in the precision of the estimates through the descriptive analysis presented in table 2.

We defined error limits of $15 \%$, but the sampling intensity was lower than required, resulting in errors larger than the pre-established limits. Such errors are due to the high variability and irregular spacing of the dead wood pieces in the forest (Miehs et al., 2010), increasing the coefficient of variation and, consequently, the sampling error.

We found the smallest sampling errors in the estimation of small pieces using LIS method (error of $17.77 \%$ ), while FA method results in higher errors (error of 26.89\%). For coarse parts errors increased, but the LIS method also showed smallest errors (38.10\%). To obtain the acceptable error for both sampling methods, we calculated the optimal number of sample units required for $15 \%$ error (Table 3).

LIS method was more accurate than the fixed area method (Table 3), resulting in a smaller relative error and fewer sample units to reach the admissible error, besides showing lower coefficient of variation in both categories of necromass studied. Woldendorp et al. (2004) verified that the coefficient of variation (CV) is

Table 2. Comparison statistics for the Line-Intersect (LIS) and Fixed Area (FA) sampling methods, Dois Irmãos State Park, Recife, Pernambuco, Brazil.

\begin{tabular}{|c|c|c|c|c|}
\hline \multirow{4}{*}{ Descriptive statistics } & \multicolumn{2}{|c|}{ Method } & \multicolumn{2}{|c|}{ Method } \\
\hline & (LIS) & (FA) & (LIS) & (FA) \\
\hline & \multicolumn{2}{|c|}{ Small pieces } & \multicolumn{2}{|c|}{ Coarse pieces } \\
\hline & $\begin{array}{c}\text { Transect } \\
50 \mathrm{~m}\end{array}$ & $\begin{array}{c}\text { Plot } \\
5 \mathrm{~m} \mathrm{x} 5 \mathrm{~m}\end{array}$ & $\begin{array}{c}\text { Transect } \\
50 \mathrm{~m}\end{array}$ & $\begin{array}{c}\text { Plot } \\
10 \mathrm{~m} \times 10 \mathrm{~m}\end{array}$ \\
\hline Number of sampling units & 20 & 20 & 20 & 20 \\
\hline Average volume $\left(\mathrm{m}^{3} \cdot \mathrm{ha}^{-1}\right)$ & 12.56 & 12.03 & 51.58 & 47.80 \\
\hline Standard deviation $\left(\mathrm{m}^{3} . \mathrm{ha}^{-1}\right)$ & 5.77 & 8.58 & 50.83 & 48.39 \\
\hline Mean variance & 1.66 & 3.68 & 129.21 & 117.08 \\
\hline Standard error & 1.29 & 1.91 & 11.36 & 10.82 \\
\hline Coefficient of variation (\%) & 46 & 70 & 99 & 101 \\
\hline Absolute sample error $\left(\mathrm{m}^{3} . \mathrm{ha}^{-1}\right)$ & 2.23 & 3.31 & 19.65 & 18.70 \\
\hline Relative error $(\%)$ & 17.77 & 26.89 & 38.10 & 39.13 \\
\hline
\end{tabular}


Table 3. Sample intensity needed to reach $15 \%$ error limit.

\begin{tabular}{|c|c|c|c|c|}
\hline \multirow{3}{*}{ Sample intensity } & \multicolumn{2}{|c|}{ Small pieces } & \multicolumn{2}{|c|}{ Coarse pieces } \\
\hline & \multicolumn{2}{|c|}{ Methods } & \multicolumn{2}{|c|}{ Methods } \\
\hline & \multicolumn{2}{|c|}{ LIS FA } & \multicolumn{2}{|c|}{ LIS FA } \\
\hline Coefficient of variation (\%) & 46 & 70 & 99 & 101 \\
\hline Relative error (\%) & 17.77 & 26.89 & 38.10 & 39.13 \\
\hline No. of sample units needed to reach $15 \%$ of error & 28 & 65 & 130 & 135 \\
\hline
\end{tabular}

Table 4. Relative efficiency of the sampling methods Line-intersect and Fixed Area.

\begin{tabular}{ccccc}
\hline Categories & Methods & Time $(\mathbf{h})$ & CV\% & RE \\
Small pieces & LIS & 15.06 & 46 & 3.13 \\
$(2 \mathrm{~cm}<\varnothing<10 \mathrm{~cm})$ & FA & 19.0 & 70 & 1.07 \\
Coarce pieces & LIS & 8.41 & 99 & 1.21 \\
$(\varnothing \geq 10 \mathrm{~cm})$ & FA & 9.85 & 100 & 1.01 \\
\hline
\end{tabular}

$\mathrm{CV}=$ Coefficient of variation (\%); RE = relative efficiency.

highly related to the sampling intensity in both sample methods, LIS and FA. Those results were also proven by Deus et al. (2018), who reported that the increasing in sample intensity decreases the coefficient of variation.

LIS method was more accurate and efficient than FA method. The smaller field time using the LIS method proves its efficiency concerning the FA method. The relative efficiency is presented in table 4 , and the method with the highest value is the most efficient.

Palace et al. (2012) reported that LIS method is six times more efficient than the AF method and takes about a third of the time and half of the team in the field, since fixed area method requires higher movement and is difficult in dense forest. However, care should be taken in choosing the best approach, as it depends on the purpose of the forest inventory and forest conditions (Bate et al., 2004). Moreover, efficiency should not be the only parameter to be taken into account when choosing a method. Most precise methods are preferred for inventories that require a high quantitative rigor, while for strategic or rapid inventory surveys, it is possible to opt for the less conventional methods, or highly efficient methods (Miranda et al., 2015).

\section{CONCLUSION}

Evaluating both methods, the LIS method was more accurate estimating arboreal necromass. It requires lower sample intensity to meet a sample error of $15 \%$ and is more efficient when compared to the FA method. However, the LIS method still requires a high sample intensity. Therefore, the LIS method seems to be more appropriate for the assessment of necromass in the Atlantic Forest. We verified that the stock of fallen dead wood accounts for about $12.28 \%$ of the total biomass above the soil in the studied forest fragment, demonstrating the importance of including necromass compartment in researches of carbon stock in tropical forests, which may account for up to $40 \%$ of the carbon found above the soil.

\section{ACKNOWLEDGEMENTS}

This study was supported by the Conselho Nacional de Desenvolvimento Científico e Tecnológico (CNPq/MCTI), Biodiversity Research Program, Brazilian Rainforest Network (PPBio-MA, Research Grant 457483/2012-1). N. C. Fonsêca received a Master's scholarship from CAPES through the Forest Sciences MSc Program at UFRPE. We thank the administration of the Parque Estadual de Dois Irmãos for research permit; E. Albuquerque and R. Berger for comments on earlier versions of the manuscript; M.A. Chagas for field assistance; and the Plant Ecology Laboratory (LEVE) for all assistance.

\section{SUBMISSION STATUS}

Received: 15 sep., 2018

Accepted: 17 mar., 2019 


\section{CORRESPONDENCE TO}

\section{Nathan Fonsêca}

Departamento de Ciência Florestal, Universidade Federal Rural de Pernambuco - UFRPE, Rua Dom Manoel de Medeiros, s/n, Dois Irmãos, CEP 52171-900, Recife, PE, Brasil

e-mail: nathanflorestal@hotmail.com

\section{FINANCIAL SUPPORT}

Coordenação de Aperfeiçoamento de Pessoal de Nível Superior, (Capes-Research Grant/1492371). Conselho Nacional de Desenvolvimento Científico e Tecnológico, (PPBio-MA, Research Grant 457483/2012-1).

\section{REFERENCES}

Associação Brasileira de Normas Técnicas - ABNT. NBR 11941. Madeira: determinação da densidade básica. Rio de Janeiro: ABNT; 2003. 6 p.

Bate LJ, Torgersen TR, Wisdom MJ, Garton EO. Performance of sampling methods to estimate log characteristics for wildlife. Forest Ecology and Management 2004; 199(1): 83-102. http://dx.doi.org/10.1016/j.foreco.2004.04.021.

Barbosa RI, Silva LFSG, Cavalcante CO. Protocolo de Necromassa: estoque e produção de liteira grossa. Boa Vista: PPBIO - Programa de Pesquisa em Biodiversidade. Ministério da Ciência e Tecnologia. Instituto Nacional de Pesquisas da Amazônia,; 2009, 24p.

Bassett M, Chia EK, Leonard SWJ, Nimmo DG, Holland GJ, Ritchie EG et al. The effects of topographic variation and the fire regime on coarse woody debris: Insights from a large wildfire. Forest Ecology and Management 2015; 340: 126-134. http://dx.doi.org/10.1016/j.foreco.2014.12.028.

Benedetti MM, Curi N, Sparovek G, Carvalho Filho A, Silva SHG. Updated Brazilian's georeferenced soil databasean improvement for international scientific information exchanging. Embrapa 2011; 1: 309-332.

Cardoso DJ, Vibrans AC, Lingner DV. Inventário da necromassa florestal caída no chão nos remanescentes florestais em Santa Catarina. In: Vibrans A.C.; Sevegnani L.; Gasper A.L.; Lingner D.V. editores. Inventário Florístico Florestal de Santa Catarina, Vol. I, Diversidade e conservação dos remanescentes florestais. Blumenau: Edifurb; 2012. p. 218-228.

Chao HJ, Phillips O. Field manual for mode of Death Census. Manaus: PAN-AMAZONIA - Project for Advancement of Networked Science in Amazonia; 2005. (Sixth Framework Programme (2002-2006)). $12 \mathrm{p}$.
Chao KJ, Phillips OL, Baker TR, Peacock J, Lopez-Gonzalez G, Vasquez Martinez R et al. After trees die: quantities and determinants of necromass across Amazonia. Biogeosciences 2009; 6(8): 1615-1626. http://dx.doi. org/10.5194/bg-6-1615-2009.

Cruz D Fo, Silva JNM. Avaliação da quantidade de resíduos lenhosos em floresta não explorada e explorada com técnicas de redução de impactos, utilizando amostragem por linha interceptadora, no Médio Mojú, Amazônia. Acta Amazonica 2009; 39(3): 527-532. http://dx.doi. org/10.1590/S0044-59672009000300006.

Deus KHP, Bonete IP, Figueiredo A Fo, Dias NA, Bonete IP. Woody necromass stock in mixed ombrophilous forest using different sampling methods. Rev. Caatinga, Mossoró 2018; 31(3): 674-680. http://dx.doi.org/10.1590/1983$21252018 \mathrm{v} 31 \mathrm{n} 316 \mathrm{rc}$.

Gove JH, Ducey MJ, Valentine HT, Williams MS. A distance limited method for sampling downed coarse woody debris. Forest Ecology and Management 2012; 282: 53-62. http://dx.doi.org/10.1016/j.foreco.2012.06.014.

Houghton RA, Lawrence KT, Hackler J, Brown LS. The spatial distribution of forest biomass in the Brazilian Amazon: a comparison of estimates. Global Change Biology 2001; 7(7): 731-746. http://dx.doi.org/10.1046/j.13652486.2001.00426.x.

Iwashita DK, Litton CM, Giardina CP. Coarse woody debris carbon storage across a mean annual temperature gradient in tropical montane wet forest. Forest Ecology and Management 2013; 291: 336-343. http://dx.doi. org/10.1016/j.foreco.2012.11.043.

Lindner A. Biomass storage and stand structure in a conservation unit in the Atlantic Rainforest-The role of big trees. Ecological Engineering 2010; 36(12): 1769-1773. http://dx.doi.org/10.1016/j.ecoleng.2010.07.017.

Lima MS, Freire FJ, Marangom LC, Almeida BG, Ribeiro EP, Santos RL. Solos florestais em fragmento de floresta urbana na Mata de Dois Irmãos, Recife, Pernambuco, Brasil. Revista Ciência Florestal 2018; 28(2): 542-553. http://dx.doi.org/10.5902/1980509832037.

Magnusson WE, Lima AP, Luizão R, Luizão F, Costa FRC, Castilho CV et al. RAPELD: a modification of the Gentry method for biodiversity surveys in long-term ecological research sites. Biota Neotropica 2005; 5(2): 6p. http://dx.doi.org/10.1590/S1676-06032005000300002.

Miranda DLC, Francio J, Santos JP, Sanquetta CR, Corte APD. Precisão e eficiência relativa de métodos de amostragem em teca. Pesquisa Florestal Brasileira 2015; 35: 247-254.

Miehs A, York A, Tolhurst K, Stefano JD, Bell T. Sampling downed coarse woody debris in fire-prone eucalypt woodlands. Forest Ecology and Management 2010; 259(3): 440-445. http://dx.doi.org/10.1016/j.foreco.2009.10.041.

Nascimento HEM, Laurance WF. Total aboveground biomass in Central Amazonian rainforests: a landscape- 
scale study. Forest Ecology and Management 2002; 168(1-3): 311-321. http://dx.doi.org/10.1016/S0378-1127(01)00749-6.

Palace M, Keller M, Hurtt G, Frolking S. A Review of above ground necromass in tropical forests, Tropical Forests. Croatia: Department of Geography of Maryland; 2012. p. 215-252.

R Development Core Team. R: A language and environment for statistical computing [online]. Vienna: R Foundation for Statistical Computing; 2016 [cited 2018 Nov 10]. Available from: <http://www.r-project.org>

Rice AH, Pyle EH, Saleska SR, Hutyra L, Palace M, Keller $\mathrm{M}$ et al. Carbon balance and vegetation dynamics in an oldgrowth Amazonian forest. Ecological Applications 2004; 14(sp4): 55-71. http://dx.doi.org/10.1890/02-6006.

Ribeiro A, Péllico Netto S, Stal LD, Leão RA, Nascimento FAF. Proposta metodológica para realização de inventário florestal de Necromassa: um estudo de caso. Scientia Forestalis, Piracicaba 2012; 40: 121-127.

Russell MB, Fraver S, Aakala T, Gove JH, Woodall CW, D'Amato AW et al. Quantifying carbon stores and decomposition in dead wood: A review. Forest Ecology and Management 2015; 350: 107-128. http://dx.doi. org/10.1016/j.foreco.2015.04.033.

Sanchez E, Gallery R, Dalling JW. Importance of nurse logs as a substrate for the regeneration of pioneer tree species on Barro Colorado Island, Panama. Journal of Tropical Ecology 2009;25: 429-437.

Sefidi K, Marvie Mohadjer MR. Characteristics of coarse woody debris in successional stages of natural beech (Fagus orientalis) forests of Northern Iran. Journal of Forest Science 2010; 56: 7-17. http://dx.doi.org/10.17221/113/2008-JFS.

Silva LFSG, Castilho CVC, Cavalcante CO, Pimentel TP, Fearnside PM, Barbosa RI. Production and stock of coarse woody debris across a hydro-edaphic gradient of oligotrophic forests in the northern Brazilian Amazon. Forest Ecology and Management 2016; 364: 1-9. http:// dx.doi.org/10.1016/j.foreco.2015.12.045.

Stinson G, Kurz WA, Smyth CE, Neilson ET, Dymond CC, Metsaranta JM et al. An inventory-based analysis of Canada's managed forest carbon dynamics, 1990 to 2008. Global Change Biology 2011; 17(6): 2227-2244. http:// dx.doi.org/10.1111/j.1365-2486.2010.02369.x.

Van Wagner CE. The line intersect method in forest fuel sampling. Forest Science 1968; 14: 20-26.

Warren WG, Olsen PF. A line intersect technique for assessing logging waste. Forest Science 1964; 10: 267-276.

Weedon JT, Cornwell WK, Cornelissen JHC, Zanne AE, Wirth C, Coomes DA. Global meta-analysis of wood decomposition rates: a role for trait variation among tree species? Ecology Letters 2009; 12(1): 45-56. http://dx.doi. org/10.1111/j.1461-0248.2008.01259.x. PMid:19016827.

Woldendorp G, Keenan RJ, Barry S, Spencer RD. Analysis of sampling methods for coarse woody debris. Forest Ecology and Management 2004; 198(1-3): 133-148. http:// dx.doi.org/10.1016/j.foreco.2004.03.042.

Zaninovich SC, Fontana JL, Genoveva Gatti M. Atlantic Forest replacement by non-native tree plantations: Comparing aboveground necromass between native forest and pine plantation ecosystems. Forest Ecology and Management 2016; 363: 39-46. http://dx.doi.org/10.1016/j. foreco.2015.12.022.

Zhou Y, Su J, Janssens IA, Zhou G, Xiao C. Fine root and litterfall dynamics of three Korean pine (Pinus koraiensis) forests along an altitudinal gradient. Plant and Soil 2014; 374(1-2): 19-32. http://dx.doi.org/10.1007/ s11104-013-1816-8. 